\title{
Månedens mineral - korund
}

Af geolog Ulla V. Hjuler, GeologiskNyt

I januar 2007 påbegyndte Geologisk Museum en ny udstillingsrække under navnet "Månedens mineral". Hver måned kan man således glæde sig over nye, spændende stykker, som ikke findes i museets permanente udstilling.

Geologisk Museum har altid haft en fortræffelig samling af flotte mineraler fra hele Verden - en samling der stammer helt tilbage fra 1600-tallet. Bl.a. er der en unik samling af sølv fra Kongsberg-minen (beliggende sydvest for Oslo i Norge), og museet besidder i øvrigt en meget omfattende samling af Grønlandsmineraler, der bringer museet blandt Verdens førende inden for dette område.

\section{Krystallografi}

Udover den permanente udstilling, der primært er systematisk anlagt, findes der også et "nørderum", kunne man næsten kalde det, hvori der gås i dybden med krystallografien, dens forfædre - heriblandt Nicolai Steno

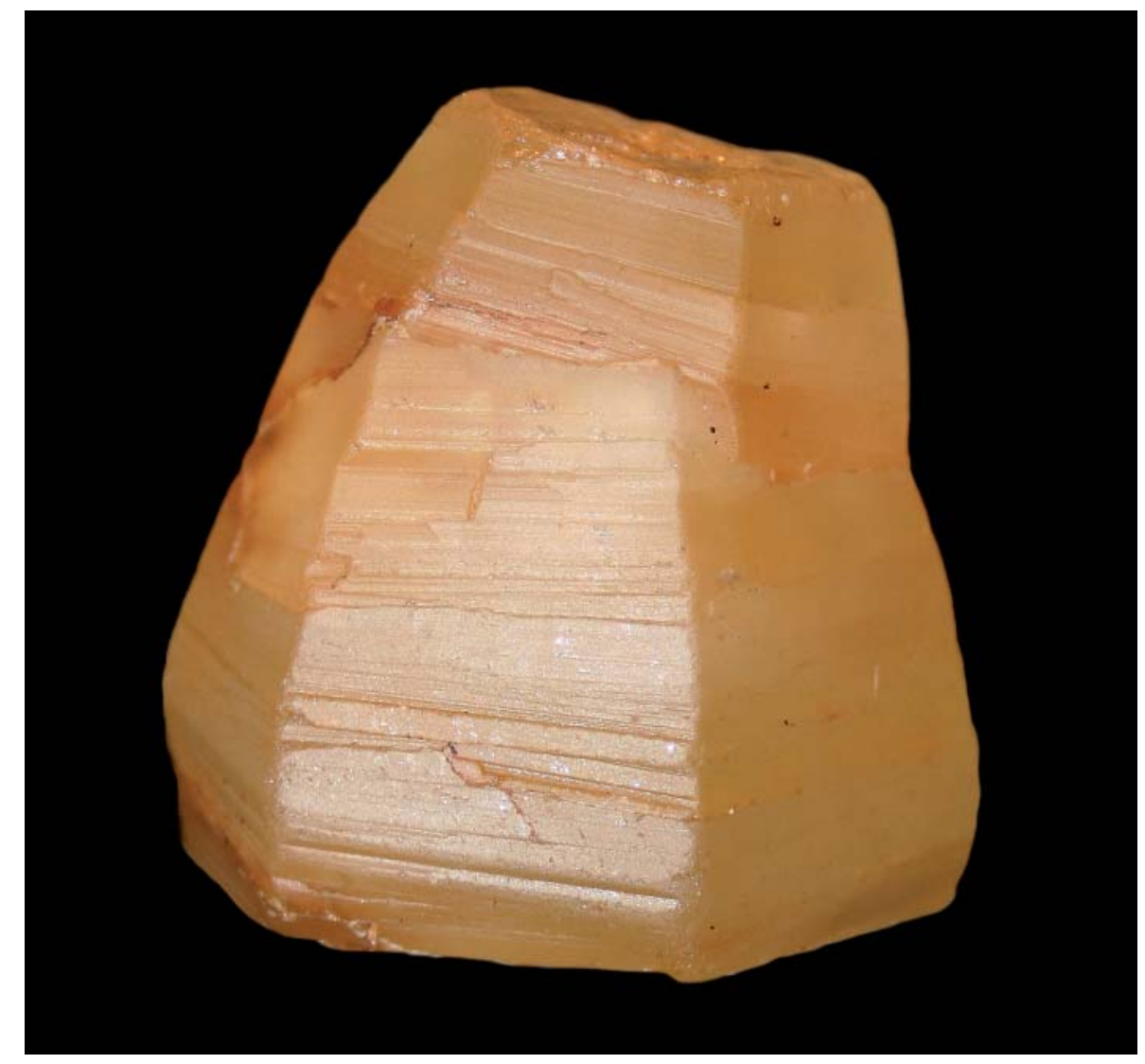

Gul safir fra Mogok, Burma. Krystallen er ca. $5 \mathrm{~cm}$ høj. Øverst et foto af små rubiner fra Fiskencesset, Grønland. (Fotos: Morten L. Hjuler) (på dansk Niels Stensen), og forskellige metoder til bestemmelse af mineraler som fx goniometret.

\section{Særudstillingen}

GeologiskNyt har kigget nærmere på korundudstillingen, der er præsenteret $i$ to

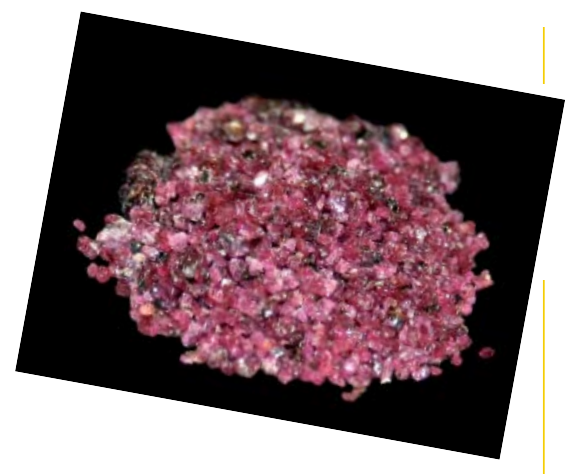

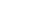

montrer uden for rummet med den permanente mineraludstilling.

Korundgruppen dækker over varieteterne rubin og safir. Rubin er den røde varietet - dens røde farve skyldes krom og de rødbrune farver jern. Varieteten safir indbefatter alle andre farver, dvs. den kendte blå (der

\section{Udvalgte egenskaber}

Kemi: $\mathrm{Al}_{2} \mathrm{O}_{3}$

Krystallografi: Trigonal. Bipyramider, tøndeformede krystaller

Hårdhed Mohs: 9

Massefylde: $4,0 \mathrm{~g} / \mathrm{cm}^{3}$

Streg: Hvid

Spaltelighed: Ingen

Farve: Rød, blå, gul, grå, grøn, farveløs

Brud: Muslet og ujævnt
Transparens: Transparent, translucent, opak

Andet: Indeslutninger af rutilnåle kan give ophav til en specielt skattet lyseffekt - en sekstakket stjerne, stjernesafirer og stjernerubiner

Forekomst: Bl.a. Sri Lanka, Burma, Thailand, Norge, Grønland, Australien, Indien, Tanzania 




Safir fra Peixe, Goiás, Brasilien. (Foto: Morten L. Hjuler)

skyldes titan) samt gule, grønne, farveløse, violette og grå farver. Anvendes navnet safir, er det underforstået, at der er tale om den blå varietet. Andre safirer er fantasisafirer og betegnes med deres farve, fx gul safir.

Det er vanskeligt at fremhæve nogle stykker frem for andre i denne udstilling, men en nyerhvervelse købt på årets München-messen med henblik på denne udstilling, fortjener dog lige et par ord med på vejen. Der er tale om en fantasisafir (se foto) fra Mogok i Burma. Den flotte gule safir er ca. $5 \mathrm{~cm}$ høj; tilsyneladende er den blevet forstyrret i væksten og er vokset "skævt" i den øverste tredjedel i forhold til den nederste del. Får man den i hånden, vil man bemærke, at den virker tung trods den kemiske sammensætning $\mathrm{Al}_{2} \mathrm{O}_{3}$. Dette skyldes, at krystalstrukturen kan betegnes som tilnærmelsesvis hexagonal tættest kuglepakning - altså en meget tæt struktur.

Udstillingen rummer mange fine stykker fra hele Verden. Faktisk skal man ikke længere væk end til Norge for at finde rubiner.

Månedens mineral er virkelig et besøg værd, og interesserede kan godt begynde at glæde sig til januar, hvor der står pyroksengruppen på programmet!

Tak til Ole Johnsen for faglig bistand.

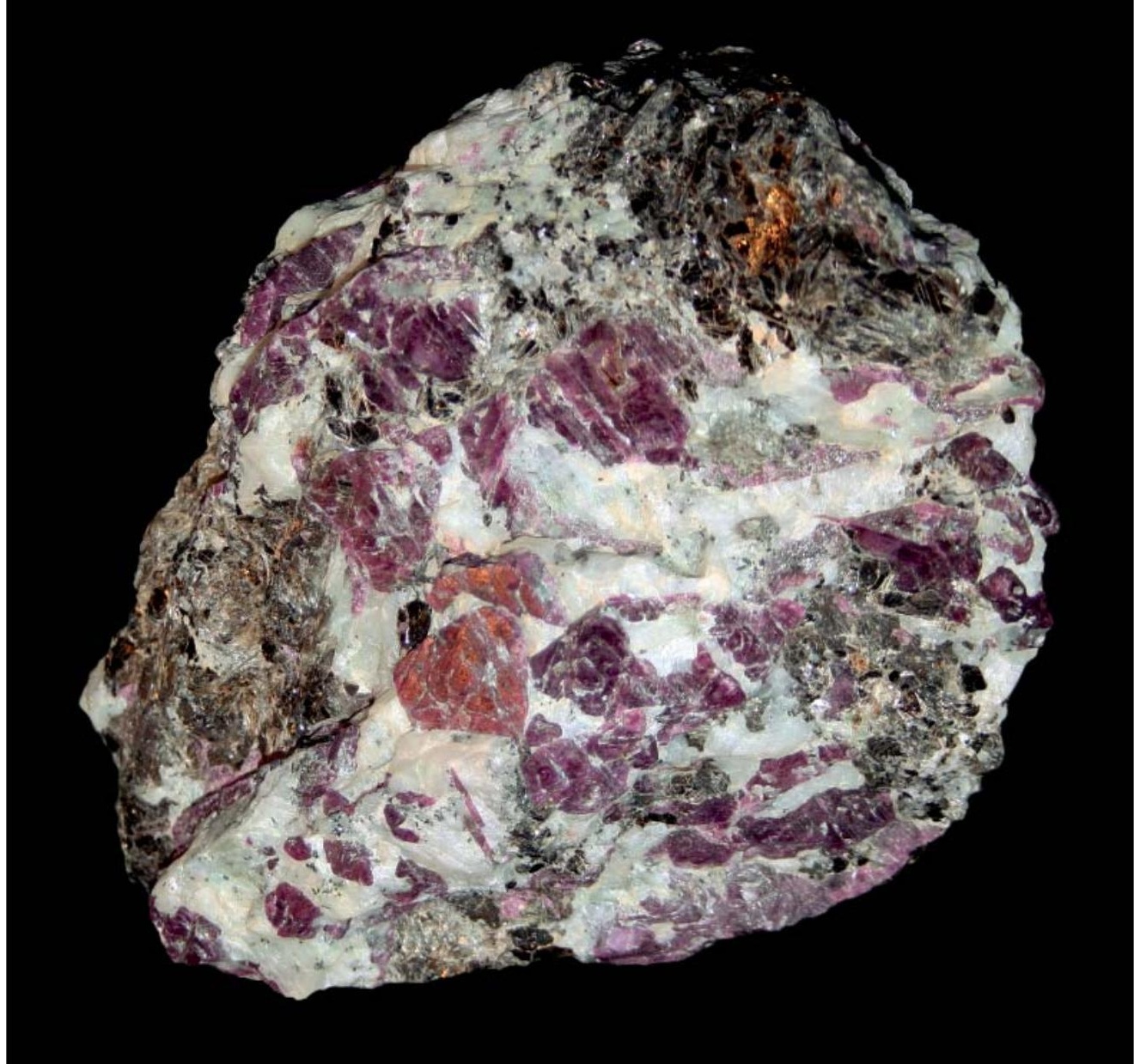

Rubin fra Arendal i Norge. (Foto: Morten L. Hjuler)

\section{Månedens mineral 2007-2009}
01.2009 Topas
02.2009 Epidot
03.2009 Dioptas 04.2009 Eudialyt 05.2009 Staurolit 06.2009 Hæmatit 07.2009 Sphalerit 08.2009 Feldspatgruppen 09.2009 Glimmergruppen 10.2009 Amfibolgruppen 11.2009 Chalcopyrit 12.2009 Turmalin

\author{
01.2008 Pyroksengruppen \\ 03.2008 Beryl \\ 05.2007 Galenit \\ 06.2007 Diamant \\ 09.2007 Sølv \\ 10.2007 Pyrit \\ 11.2007 Halit \\ 12.2007 Olivin
}

12.2007 Kryolit 